\title{
Using Camtasia Videos in Assigned Projects for Middle East University Students and their Attitudes towards it
}

\author{
Dr. Wafa Muhanna \\ Associate Professor \\ Al al-Bayt University \\ Jordan
}

\begin{abstract}
The purpose of the study is to investigate the attitudes of Master educational technology students at Middle East University towards using Camtasia Videos in Assigned Projects; it aims also to investigate the effect of students' specialization at the bachelor degree, and their gender on their attitudes. The sample of the study was selected purposefully. It consisted of (40) female Master degree students at Middle East University. a questionnaire was distributed among them. The findings of the study indicated that there are no statistically significant differences at $(\alpha=0.05)$ in students' attitudes towards using Camtasia Videos in Assigned Projects due to their specialization at the bachelor level variable. Results also showed that there are statistically significant differences at $(\alpha=0.05)$ in master students' attitudes due to their specialization in Bachelor degree in favor students whose specialization educational technology. Post hoc test using Scheffe Method was conducted to find out Multiple Comparisons differences, results showed that there are statistically significant differences at $(\alpha=0.05)$ between two sexes and in favor of males.
\end{abstract}

Keywords: Camtasia Studio, Camtasia videos, Master Students at Middle East University

\subsection{Introduction}

Using technology in teaching spread widely all over the world, different tools are used by educators one these tools is Camtasia. It is a program that produces high-quality video clips. Through the Camtasia Recorder, one can capture events in the screen and save them as video files. The above record is saved to be run and processed later with Camtasia Producer.

The program supports AVI format and standard video for Windows. We can modify the video created by Recorder with other AVI editors and use AVI files from any source in Camtasia Producer. Camtasia Studio provides real video performance for desktop activity and compressed format through the TSCC TeachSmith Screen Capture Codec. The program consists of five applications:Camtasia Recorder, Camtasia Producer, Camtasia Effects, Camtasia MenuMaker, and Camtasia Player. (Al Rajhi, 2017)

The program is a set of tools in a single panel or one place one can control as he likes to shoot videos on the computer, this program was famous in late 2014 all over the world in the western countries, while in the Arabic world it is famous since 2015-2016.

This program is fantastic because it can make montage even in pictures and adjust the sound, pictures, and many things, but the negatives are tend to be lacking since there has not been even a mistake or a defect in it.This program can even photograph your face as most games do, and the trick in the program is the difficulty of montage for beginners. http://sawawir.blogspot.com/2017/06/camtasia-studio.html

Camtasia Studio program through which you can produce videos and educational explanations where you can take the different images of the screen and add texts to them and the production of videos and explanations are done in three stages: the first stage recording and the second editing and third production. These stages are obtained through your video where the recording process begins using the program Camtasia Studio by video recording and control settings, set the program and capture the entire screen images and add effects and recording audio clips using the means provided by the program Camtasia in the recording stage, after that comes the editing stage which allows you to add effects to the screen, which helps to explain the explanation provided within the video, you can also add text and some movements to these texts and can be placed in the animation program Camtasia Studio 
Which gives you many options to improve the quality of sound and also contains a library of documents which can be used for free, then the video production stage is the easiest stage because it does not contain any problems because Camtasia Studio has settings that help to select the details of the output of a clear video can be fully control the degree of video clarity and size you want, it can also be played in addition to the video format until it produces a professional video that can be shared via YouTube or social networking sites.

https://www.bramgy.net/2018/08/download-camtasia-studio-apk.html

\section{What to do with Camtasia Studio:}

- Record screen activity as a video file that can be edited, and the final view can be published in standard format.

- Create Macromedia Flash Video.

- Publish video as standard AVI files or streamed presentations from websites.

- Register websites as if we are connected and view Internet information without having to contact.

- Documenting meetings via web.

- Control video length, adjust content size, correct errors without re-recording video, and cut faulty video.

- Capture cursor movement, selected menu, windows, write and everything on the screen.

- Use Camtasia Screen Draw to draw on the desktop while recording video.

- Use Screen Pad to add comments, logos and graphics.

- Use Camtasia Effect to add stock and images to your video.

- Use Camtasia Menu Maker to create menus.

- Produce Flash or AVI files.

- Video compression.(Al Rajhi, 2017)

Recently universities ask faculty members and students to use such technology in the class because it enhance creative thinking and successful learning.

\subsection{Purpose of the study}

The purpose of this study is to investigate the attitudes of undergraduate students at Middle East University towards using Camtasia Videos in Assigned Projects; it aims also to investigate the effect of students' gender and students' specialization on their attitudes.

\subsection{Statement of the Problem}

Hardware and software programs are combined by Camtasia videos to create an interactive show that allows presenters to display and manipulate information on the screen for the audience to view. This technology operates by touch or by pens, and it is used for business presentations or lessons in the classroom. Camtasia studio is a useful tool; however, there are challenges users commonly face while using the Camtasia. The researcher tried to investigate the effectiveness of using this valuable and effective technology in learning at Middle East University by investigating undergraduate students' attitudes towards using this program.

\subsection{Questions of the study}

To achieve the objectives of the study, the following questions were formulated:

1- What are the undergraduate students' attitudes at Middle East University towards using Camtasia videos in assigned projects?

2- Are there any statistically significant differences between the attitudes of the undergraduate students due to their gender (Male, Female)?

3- Are there any statistically significant differences between the attitudes of the undergraduate students at Middle East University due to their specialization in bachelor degree (educational technology, business, others)?

\subsection{Significance of the study}

Using technology in the classroom is constantly increasing and evolving. The importance of introducing students to current technology is part of their education and to prepare them for the future. One of the new technological advancement that is widely used in education nowadays is Camtasia videos to increase a student's knowledge and enhance them to do their projects effectively. The researcher has seen Camtasia videos in use in class setting and she has only found it beneficial and interesting.

The researcher was able to witness the excitement that students get when using Camtasia videos in learning. Students are excited to learn and Camtasia videos make lessons exciting and benefit. 


\subsection{Operational Definition of Terms}

Camtasia Studio: is a software suite, created and published by TechSmith, for creating video tutorials and presentations directly via screen cast, or via a direct recording plug-in to Microsoft PowerPoint.

Camtasia videos: videos which can be created by Camtasia Studio 8 with custom music, templates and easy-touse point, and these videos could be produced in one or multiple formats for the web, YouTube or mobile devices such as iPhones and iPads or Andriods.

\subsection{Limitations of the study}

This study is limited to all undergraduate students at Middle East University at the Academic year 2016/2017, and to all similar samples.

\section{Literature Review}

Recently, interest in using technology in teaching increased, and many studies were conducted to study the effectiveness of using different types of technology such as computer, Camtasia, PowerPoint,....etc in teaching. The researcher reviewed some of these studies as follows:

Salina, et.al, (2012) study aimed to identify the effectiveness of the use of instructional video as a tool for updating and enhancing the learning of some nursing skills among the students of the Faculty of Nursing at the University of Tyrn, the researchers used the experimental approach, the study was carried out after taking a sample of 21 students in 2009 to identify the points of deficiency and the size of the appropriate sample for the study. Then, a random sample of (223) students was selected, consisting of two experimental groups of (112), While the number of control group reached (111) students. Both groups studied the traditional method. After a month, the experimental group studied the skills required by using educational videos to review their skills, while the control group reviewed these skills in the traditional way. A 33-point skills card was assessed to measure differences between the two groups. The study found that the experimental subjects were able to apply these skills more than the control group, with a high level of proficiency, and that the video sites significantly contribute to enhancing students' learning and taking into account their special needs, and recommended that video should be used as an educational tool through electronic video sites as one of the most important tools of elearning and for its great educational benefit.

Chtouki, et.al (2012) study aimed to identify the effect of using YouTube in enhancing student learning and evaluating their cognitive skills in a course in computer science for students from other disciplines. The experimental method was used in this study, the sample of the study composed of (150) students, divided into experimental sample studied using videos published electronically on YouTube, these sections dealt with the theoretical concepts of the course, while the control group was taught using regular sources such as books and theoretical lectures. The questionnaire and cognitive testing tool was used to obtain the results of the study, in which the experimental group exceeded the control in the cognitive test, which was applied to one of the most difficult subjects of the course, where $65 \%$ of the experimental sample succeeded in the test compared with 50\% of the control sample. The students also believe that the use of YouTube in education increases their motivation to learn and increases their knowledge by searching for similar videos. The study recommended making YouTube a useful educational resource used by educators to improve the skillful performance of students.

Kavas\& Ozdener (2012) study aimed to identify the effectiveness of an electronic video site on the development of teachers' skills in teaching at Ataturk College, Marmara University, Turkey, and used the experimental method that was applied to the sample of the study consisting of two randomly selected groups. The sample of the study which include (21) students was taught using video sites outside the course hours, and the control group with 21 students did not study outside the hours of the course schedule, and the research tools included pre and posttests of the two groups, a note card and a trend scale, as well as an electronic skills assessment model approved by the University, the study found that there were clear differences in the skills of teaching in the school for the benefit of the experimental group, as well as in the skills of mini-teaching in front of peers, and that $71 \%$ of the members of the experimental group considered that their assessment reflects their true level, all members of the group acknowledged that the videos helped them develop their teaching skills. The study recommended the use of an integrated web-based video-based system in skills training, as it gives trainees greater opportunity to do more meaningful activities. 
Burger (2011) aims in this study to measure the effectiveness of electronic video sites for non-graduate students in the course "Introduction in the Department of Graphic Arts and Photography (GCM),(10) videos were recorded using screen recording programs, and uploaded to a special server in the university applied by the University Stout, to be available at any time needed by students, and the descriptive method was used, which was applied to a sample of (40) university students enrolled in that course, and a questionnaire was distributed in order to identify the effectiveness of the video in improving their learning, and making it more efficient, the study concluded that the video helped them understand the theoretical concepts, practical skills, and encouraged them to learn significantly, there have been positive trends in their ability to control the learning process by controlling the delivery and return of video. The study recommended the need to provide scientific laboratories with many related videos and the need to ensure that the video works on all computers.

Seyal's (2010) study aimed at identifying students' attitudes towards e-learning through professional and technical education in Brunei Darussalam, the study examined 220 students from the professional and technical institutions and colleges to evaluate their attitudes toward e-learning. The study used the analytical survey statistical method and the social statistical packages program (SPSS), in order to collect the data, a questionnaire was distributed to a random sample of students in order to evaluate the attitudes of the learners toward e-learning, whether there was an impact on the demographic factors, and to develop a tool to measure students' attitudes toward e-learning. The study showed that there are positive attitudes of the the students towards e-learning, and that the management of the colleges should design and form an information technology policy on the development of laboratories for students and that students should train and prepare for learning and e-learning.

Al-Khalifa (2009) conducted a study aimed at identifying trends and modern developments in the e-learning service: a comparative study between the four models of distance learning, computer-based or internet-based training, electronic or computer electronic performance support systems, asynchronous virtual classes, and synchronized virtual classes. The study aimed to compare the four models and provide a detailed definition of each model in terms of its objectives, characteristics, selection criteria and examples. The study concluded that a combination of these four models could be used at the same time to build comprehensive and integrated learning systems.

Al Ahmad Study (2007) conducted a study entitled "The Effect of Using Presentation Program (PowerPoint) on the achievement of students in the sixth grade in science in Riyadh). The study aimed at identifying the effect of using the PowerPoint program in the achievement of the students of the sixth grade in the science course in Riyadh city. The researcher relied on the semi-experimental approach. The sample included (56) students, the study tools consisted of the PowerPoint program and an achievement test that measures students' achievement. The study concluded the following results: There were statistically significant differences between the mean of the experimental group and the control group in the post-achievement test. There were also statistically significant differences between the mean scores of the experimental group in the pre achievement test and their grades in the post-achievement test in favor of the post-test.

\section{The Methodology of the Study}

\subsection{The population of the study}

The population of the study consisted of all male and female students at Faculty of Education at Middle East University, who are about (150) students during the second semester 2016/2017.

\subsection{The sample of the study}

The sample of the study will be selected purposefully. It will consist of (40) male and female undergraduate students at Middle East University. This sample will be used to measure their attitudes towards using Camtasia videos in their assigned projects and a questionnaire will be distributed among them.

\subsection{The instrument of the study:}

\subsubsection{A Questionnaire}

A questionnaire was distributed among the undergraduate students at Middle East University and this questionnaire was designed by the researcher herself, it consisted of (30) items. Many variables will be included such as the gender of the students and the specialization of the students at the bachelor degree. 


\subsection{Validity of the instrument}

The researcher designed a questionnaire about undergraduate students' attitudes towards using Camtasia videos in their assigned projects. The researcher validated the instrument by submitting it to a jury of supervisors and professors of technology. The researcher followed the recommendations of the referees and made amendments accordingly.

To extract the construct validity, correlation coefficients of the items of the questionnaire with the total score were extracted in the pilot sample outside the study sample which consisted of (5) students.

\subsection{Procedures of the Study}

To achieve the purpose of the study, the following procedures were used:

A questionnaire about undergraduate students' attitudes towards using Camtasia videos in their assigned projects was given to (40) male and female undergraduate students. After that the researcher collected the questionnaires and the data, and then this data was analyzed statistically.

The researcher did the following:

1. Reviewing the literature review

2. Assigning the population and sample of the study.

3. Preparing the questionnaire.

4. Validity and reliability were insured.

5. Applying the pilot study.

6. Applying the questionnaire on the sample of the study.

7. Collecting the questionnaires.

8. Analyzing the collected data.

9. Results were found.

10. Discussing the results.

11. Recommendations were proposed to the concern.

Findings of the study, Discussions and Recommendations

\subsection{Findings of the study}

The purpose of this study is to investigate the attitudes of Master educational technology students at Middle East University towards using Camtasia Videos in Assigned Projects; it aims also to investigate the effect of students' specialization at the bachelor degree, and their general point average (specialization) on their attitudes.

\section{Results of the first question}

Question one: What are the Master students' attitudes at Middle East University towards using Camtasia videos in assigned projects?

To answer the first question of the study, means and standard deviations of the students' responses on questionnaire items were computed as presented in table (1)

Table (1): Means and standard deviations for items in the questionnaire, ranked in a descending order

\begin{tabular}{|l|l|l|l|l|}
\hline Rank & N & Item & Mean & $\begin{array}{l}\text { Std. } \\
\text { Deviation }\end{array}$ \\
\hline 1 & 12 & I like the use of "Camtasia videos" better than textbook & 4.12 & .812 \\
\hline 2 & 2 & I use Camtasia videos "" to help me in the project design & 4.05 & .748 \\
\hline 3 & 10 & $\begin{array}{l}\text { "Camtasia videos" are useful because I can take steps to } \\
\text { project according to my own time }\end{array}$ & 4.04 & .734 \\
\hline 4 & 7 & "Camtasia videos" are easy to follow & 4.03 & .852 \\
\hline 5 & 6 & $\begin{array}{l}\text { "Camtasia Videos" are useful so that I can carry my own } \\
\text { speed }\end{array}$ & 3.99 & .890 \\
\hline 6 & 8 & Action steps in "Camtasia" are well shown & 3.97 & .942 \\
\hline 7 & 24 & $\begin{array}{l}\text { I prefer using camtasia studio program because it is fun } \\
\text { and attracted me }\end{array}$ & 3.95 & .864 \\
\hline 8 & 15 & Using "Camtasia videos" save more effort & 3.93 & .834 \\
\hline 9 & 14 & When I use "Camtasia videos" programs I,m encouraged to & 3.91 & .845 \\
\hline
\end{tabular}




\begin{tabular}{|c|c|c|c|c|}
\hline Rank & $\mathrm{N}$ & Item & Mean & $\begin{array}{l}\text { Std. } \\
\text { Deviation }\end{array}$ \\
\hline & & finish my project & & \\
\hline 10 & 3 & $\begin{array}{l}\text { I use Camtasia videos "" to help me in the presentation of } \\
\text { projects }\end{array}$ & 3.90 & .884 \\
\hline 11 & 5 & $\begin{array}{l}\text { "Camtasia videos" help me to understand the concepts and } \\
\text { I will not need extra help }\end{array}$ & 3.90 & .850 \\
\hline 12 & 17 & $\begin{array}{l}\text { I'm not having trouble when using camtasia studio program } \\
\text { because it supports the Arabic language }\end{array}$ & 3.89 & .852 \\
\hline 13 & 20 & $\begin{array}{l}\text { to design professional videos I prefer best the use camtasia } \\
\text { studio program }\end{array}$ & 3.89 & .855 \\
\hline 14 & 23 & $\begin{array}{l}\text { recording the sound in camtasia studio program is with a } \\
\text { high-quality }\end{array}$ & 3.89 & .745 \\
\hline 15 & 9 & Writing in "Camtasia videos" is easy to read & 3.86 & .893 \\
\hline 16 & 21 & $\begin{array}{l}\text { Camtasia studio program allows keeping different videos } \\
\text { with versions to be able to share with others }\end{array}$ & 3.86 & .835 \\
\hline 17 & 22 & $\begin{array}{l}\text { I prefer using camtasia studio software to easily convert } \\
\text { files to the current versions of files }\end{array}$ & 3.86 & .867 \\
\hline 18 & 18 & $\begin{array}{l}\text { Camtasia studio program allows adjustment feature on the } \\
\text { media (audio, and video clips) }\end{array}$ & 3.85 & .877 \\
\hline 19 & 11 & $\begin{array}{l}\text { "Camtasia videos" help me understand the procedures of } \\
\text { the project better }\end{array}$ & 3.83 & .855 \\
\hline 20 & 1 & $\begin{array}{l}\text { Using of Camtasia "videos" helps a lot to understand the } \\
\text { perception of what is happening }\end{array}$ & 3.82 & 1.013 \\
\hline 21 & 13 & $\begin{array}{l}\text { watching projects designed by "Camtasia videos" is fun } \\
\text { and interesting }\end{array}$ & 3.82 & .911 \\
\hline 22 & 4 & "Camtasia videos" are useful and full of rich potentials & 3.78 & .903 \\
\hline 23 & 16 & $\begin{array}{l}\text { When referring to a part in a video clip or edit it in a better } \\
\text { way I prefer to use camtasia studio program because there } \\
\text { is a lack of this feature in other programs }\end{array}$ & 3.72 & 1.008 \\
\hline \multirow[t]{2}{*}{24} & 19 & $\begin{array}{l}\text { Camtasia studio program features the possibility of transfer } \\
\text { of live and recorded it }\end{array}$ & 3.70 & .991 \\
\hline & & Total & 3.90 & .428 \\
\hline
\end{tabular}

Table (1) shows that the means and standard deviations of the whole answers were 3.90,428. it also shows that Item 12 " I like the use of Camtasia videos better than textbook " receives the highest mean (4.12) regarding the degree of agreement with a standard deviation of (0.812), then the second item 2 comes next (I use Camtasia videos to help me in the project design) with a mean of (4.05) and standard deviation of (0.748). This result may be due to the entertainment students have when dealing with technology. Instructors rarely help their students to use computer programs; they usually concentrate on lecturing.

Meanwhile, the lowest was item number 19 (Camtasia studio program features the possibility of transfer of live and recorded it) with a mean of (3.70) and standard deviation of (0.991), then item number 16 (When referring to a part in a video clip or edit it in a better way I prefer to use camtasia studio program because there is a lack of this feature in other programs) with a mean of (3.72) and standard deviation of (1.008). In fact, these two items got the lowest mean because these two features are available nearly in most computer programs not only in Camtasia studio.

\section{Results of the second question}

Question two: Are there any statistically significant differences between the attitudes of Master degree students due to their gender (male, female)?

To find out whether there are statistical significant differences in the attitudes of Master Students' due to gender variable, t-test analysis was conducted and the results are shown in table (2) 
Table (2): t-test results of students' response related to gender in bachelor degree

\begin{tabular}{|l|l|l|l|l|l|l|}
\hline Gender & $\mathrm{N}$ & Mean & $\begin{array}{l}\text { Std. } \\
\text { Deviation }\end{array}$ & $\mathrm{t}$ & $\mathrm{df}$ & $\begin{array}{l}\text { Sig. } \\
\text { (2-tailed) }\end{array}$ \\
\hline Male & 11 & 3.90 & .417 & -.021 & 186 & .983 \\
\hline Female & 19 & 3.90 & .436 & & \\
\hline
\end{tabular}

Table (2) shows that there are no statistically significant differences at $(\alpha=0.05)$ in Master students' attitudes towards using Camtasia videos in their assigned projects at Middle East University due to gender variable. This is because all students with in both sexes benefit from technology.

\section{Results of the third question}

Question three: Are there any statistically significant differences between the attitudes of Master degree students due to their specialization at the bachelor level (low, mid, high)?

To find out whether there are statistical significant differences in the attitudes of Master Students due to their specialization at the bachelor level variable, t-test analysis was conducted and the results are shown in table (3).

Table (3): t-test results of Master students' response related to their specialization at the bachelor level

\begin{tabular}{|l|l|l|l|}
\hline specialization & N & Mean & Std. Deviation \\
\hline Educational technology & 4 & 3.75 & .482 \\
\hline business & 9 & 3.88 & .339 \\
\hline others & 17 & 4.00 & .427 \\
\hline Total & 30 & 3.90 & .428 \\
\hline
\end{tabular}

Table (3) shows a slight variance in the means according to specialization variable; specialization proves to have a great role on their attitudes because they interpret the surrounding environment and the whole educational process in a scientific way.

To find out whether there are statistical significant differences in these means, one way ANOVA was conducted; results are shown in table (4).

Table (4): One way ANOVA results of Master students' attitudes due to their specialization

\begin{tabular}{|l|l|l|l|l|l|}
\hline & Sum of Squares & df & Mean Square & F & Sig. \\
\hline Between Groups & 1.880 & 2 & .940 & 5.865 & .003 \\
Within Groups & 29.654 & 185 & .160 & & \\
Total & 31.534 & 187 & & & \\
\hline
\end{tabular}

Table (4) shows There are statistically significant differences at $(\alpha=0.05)$ in the Master students' attitudes towards using Camtasia videos in their assigned projects at Middle East University due to specialization variable, to find out Multiple Comparisons differences post hoc test using Scheffe Mehod was conducted as shown in table (5)

Table (5): Multiple Comparisons post hoc test using Scheffe Method due to specialization

\begin{tabular}{|l|l|l|l|l|}
\hline \multirow{2}{*}{$(\mathrm{I})$ specialization } & $(\mathrm{J})$ specialization & $\begin{array}{l}\text { Mean Difference (I- } \\
\mathrm{J})\end{array}$ & $\begin{array}{l}\text { Std. } \\
\text { Error }\end{array}$ & Sig. \\
\hline \multirow{2}{*}{ ET } & business & -.13 & .083 & .318 \\
\cline { 2 - 5 } & others & $-.24\left(^{*}\right)$ & .076 & .006 \\
\hline \multirow{2}{*}{ business } & ET & .13 & .083 & .318 \\
\cline { 2 - 5 } & others & -.12 & .072 & .265 \\
\hline \multirow{2}{*}{ others } & ET & $.24\left(^{*}\right)$ & .076 & .006 \\
\cline { 2 - 6 } & business & .12 & .072 & .265 \\
\hline
\end{tabular}

* The mean difference is significant at the .05 level. 
Table (5) shows There are statistically significant differences at $(\alpha=0.05)$ in the Master students' attitudes towards using Camtasia videos in their assigned projects at Middle East University between ETstudents and high specialization students in favor of others specialization students. No one can deny the role of previous background especially in the educational field. Master students whose specialization is ET definitely know all types of problems that face students in using technology, and most of them could reduce or completely overcome most of these problems.

\section{Discussion}

A number of instructors may not be aware of the benefits of using Camtasia studio in their presentations as a teaching tool. While using the traditional ways already has everyone's attention, the electronic device is a new technology that is slowly gaining popularity due to its interactive power.

Using technology in education has become an independent science with the foundations on which it is based. There is no longer confusion between the educational technology and the modern educational methods, which have been prepared by some synonyms, where modern educational means, represent the practical aspect of education technology, using videos and new means such as Camtasia and PowerPoint also proved to be very effective in teaching, many studies proved that and this study also showed the effectiveness of using Camtasia studio. In fact, all these new technologies will not be effective if not employed in an accurate way through well trained teachers.

\section{References}

Al- Ahmad (2007) the impact of the use of the PowerPoint program on the achievement of sixth grade students in the science curriculum in Riyadh, unpublished master thesis, Department of Educational Technology and Methods, Faculty of Education, Deanship of Graduate Studies, King Saud University, Riyadh, Kingdom of Saudi Arabia.

Al-Khalifa (2009) Trends and Recent Developments in E-Learning: A Comparative Study of the Four Models of Distance Education, College of Computer and Information Systems, King Saud University, Riyadh, Saudi Arabia.

Al Rajhi, L. (2017) Video and Educational TV Lab, Lab 9, King Abdul-Aziz University, Saudi Arabia

Burger, R. (2011): The Impact of Streaming Video Tutorials on Undergraduate Students' Performance in Introductory Graphic Communications Management Class, A Research Paper Submitted in Partial Fulfillment of the Requirements for the Master of ScienceDegree in Career and Technical Education, University of Wisconsin Stout.

Bauk, S. \& Radlinger,R. ( 2013) Teaching ECDIS by Camtasia Studio: Making the Content more Engaging, the International Journal on Marine Navigation and Safety of Sea Transportation, Vol. 7 (3)

Chtouki, Y., Harroud, H., Khalidi, M., Bennani, S (2012): TheImpact of YouTube Videos on the Student's Learning, Information Technology Based Higher Education and Training (ITHET), International Conference, 21-23 June 2012.

Kavas,G., Ozdener, N. (2012): Effects of Video-Supported Web Based Peer Assessment on Microteaching Applications: Computer Teacher Candidates Sample, Scientific Research (Creative Education Journal), Vol.3 (7), pp. 1220-1230.

Salina,L., Ruffinengo, C., Garrino, L., Massariello, P., Charrier, L,. Martin, B., Favale, M., Dimonte, V. (2012): Effectiveness of an educational video as an instrument to refresh and reinforce thelearning of a nursing technique: a randomized controlled trial, Springer Journal, Vol. 1 (2), pp. 67-75, May 2012.

Seyal,Afzaal, H. and others,(2010): Understanding Students' Attitudes TowardE- Learning: Evidence From Bruneian Vocational and Technical Education, Faculty of Business and Information Technology, Brunei.

Tech Smith Coorporation, Camtasia Studio - Help File Document, Release 8.0, June 2012, pp. 39-47 (Web resource: http://assets.techsmith.com-/Docs/pdf- camtasia Studio/Camtasia_Studio_8_Help_File.pdf; downloaded: March, 2015)

Tech Smith Coorporation, Camtasia Studio 8 - Create Engaging Screencasts, Release 8.0, June 2012.(Web resource: http://assets.techsmith.com/Docs/pdf- camtasia Studio/ Create_Engaging_Screencasts(1).pdf; downloaded: March, 2015)

Web resource:

https://download.lightbook.org

http://www.techsupportalert.com

https://www.stir.ac.uk/media/schools/is/documents/using_camtasia_studio7.pdf

http://sawawir.blogspot.com/2017/06/camtasia-studio.html

https://www.bramgy.net/2018/08/download-camtasia-studio-apk.html 